\title{
Effects of Tracheal Instillation of Natural Surfactant in Premature Lambs. I. Clinical and Autopsy Findings
}

\author{
FORREST H. ADAMS, ${ }^{(3)}$ BERNARD TOWERS, ALAN B. OSHER, MACHIKO IKEGAMI, TETSURO \\ FUJIWARA, AND MASAHIKO NOZAKI
}

Division of Cardiology, Department of Pediatrics UCLA School of Medicine, Los Angeles, California, USA

\begin{abstract}
Summary
Ten pairs of twin lambs 118-122 days of gestation were given either natural surfactant or diluent endotracheally before the first breath. By using the premature twin lamb model, we have been able to show that instillation of natural surfactant produced $100 \%$ survival for the duration of the study period $(2 \mathrm{hr})$; stable blood gases on room air; lungs that became increasingly compliant while on the respirator; generally well aerated lungs at autopsy; good lung pressure-volume relationships; normal lung surface tension measurements; and histologic evidence of good alveolar expansion with large amounts of free intraluminal phospholipid, no epithelial damage, and no hyaline membranes. It is concluded that tracheal instillation of natural surfactant into the premature lamb protects the lungs from developing many features characteristic of the respiratory distress syndrome.
\end{abstract}

\section{Speculation}

The success of these experiments is possibly due to the use of "whole" natural surfactant rather than some of its component chemicals. The precise biochemistry and physical chemistry of surfactant is very controversial, and for therapeutic purposes, it might be best for the moment to concentrate on the natural biologic product.

It has been demonstrated that the lungs of infants dying of respiratory distress syndrome (RDS) possess abnormal surface properties $(5)$ and low levels of phospholipids $(2,9,10)$. It has also been shown that the quantity and quality of surface-active phospholipids (surfactant) increase as the fetus approaches term $(1,8$, 22 . 24), and that a large amount of surfactant is secreted into the alveolar space after the onset of respiration $(1,3,23,24)$.

Earlier studies by us ( 1 ) in human fetuses and infants were compatible with the hypothesis that hyaline membrane disease is due to a prenatal deficiency of lung surfactant. The question still remained, however, as to whether the low level of surfactant found in RDS was due to a prenatal deficiency or to some perinatal event or factors. Using prematurely delivered twin lambs, we were able to show (3) that the development of respiratory distress and hyaline membrane formation were related to a prenatal deficiency of "alveolar" disaturated phosphatidyl choline. These findings of biochemical immaturity of the lung suggested that one possible approach to the treatment or prevention of RDS in prematures might be the introduction of surfactant into the lungs.

Chu et al. (11) attempted to treat infants with RDS by using an aerosol of dipalmitoyl lecithin (DPL) in freon. Although they demonstrated deposition of DPL in peripheral lung tissue, improvement in lung compliance was inconsistent and short lived. On the other hand, studies by Shannon et al. (30) suggested that DPL nebulized in saline was capable of restoring pressure-volume relationships in surfactant-reduced excised adult dog lungs.
Our recent studies (25) using surfactant depleted adult rat lungs suggest that nebulization of either synthetic DPL or natural surfactant is not an effective way to restore lung pressure-volume characteristics, but that direct tracheal instillation of natural surfactant is very effective. Along these lines of investigation, Enhörning and his collaborators $(18,20)$ have shown that tracheal deposition of surfactant into premature rabbit fetuses before the first breath enhanced air intake and improved the pressure-volume relationships of the lungs; it also increased the survival time (18). Similar results were obtained with pharyngeal deposition of surfactant before the onset of respiration in rabbits (19).

The purpose of our present investigations was to determine in a more extensive way if the direct tracheal instillation of natural surfactant into a prematurely delivered lamb has a favorable effect on its clinical status and postmortem findings. The twin lamb model was chosen because of the larger size of the animals which permits measurement of more parameters and the use of one as a control and the other as the experimental lamb, thus reducing the problems associated with variations in gestational age, nutritional state, size, and other factors. Moreover, it appeared to us that if the results were favorable in lambs weighing $1-2 \mathrm{~kg}$, a more direct application could be made to the treatment or prevention of RDS in human premature babies.

\section{MATERIALS AND METHODS}

\section{PROTOCOL FOR ANIMALS}

Ten pregnant ewes between 118 and 122 days of gestation known by $x$-ray examination to possess twin fetuses were used. The ewes were premedicated with $10 \mathrm{mg}$ Valium and after spinal (Xylocaine) anesthesia was established, the offspring were delivered in sequence. Arterial blood was obtained from each ewe for determination of $\mathrm{pH}, \mathrm{pO}_{2}$, and $\mathrm{pCO}_{2}$ on a Radiometer blood microsystem and corrected for body temperature. Amniotic fluid and tracheal fluid were obtained from each fetus for determination of surface activity by the "shake test" (13).

The trachea of each fetus was cannulated with a standard endotracheal tube just before the delivery of the entire fetus. The tip of the cannula was positioned just proximal to the origin of the right upper lobe bronchus, which is above the carina in the sheep. Tracheal fluid was collected, and the cannula was then clamped. Umbilical vein blood was obtained from each fetus for $\mathrm{pH}, \mathrm{pO}_{2}$, and $\mathrm{pCO}_{2}$, after which the umbilical cord was tied.

On an alternate basis, each twin lamb was assigned to one of two groups: experimental or control. The experimental lamb received $15 \mathrm{ml}$ natural surfactant suspended in either saline or water instilled directly into the tracheal cannula prior to the first breath. The control lamb received a similar volume of fluid containing only the diluent (six were normal saline; four were distilled water) prior to the first breath. During the instillation, which took about $30 \mathrm{sec}$, the animal's position was changed 
continuously to facilitate entry of the instillate into each lobar and segmental bronchus. Each lamb was then quickly ventilated by hand once with $100 \%$ oxygen and then ventilated with room air (to avoid the complications of oxygen toxicity) at $21^{\circ}$ and $50 \%$ humidity using a small animal volume respirator (Harvard). The initial respirator settings were with a rate of $60 / \mathrm{min}$, a volume of $5 \mathrm{ml} / \mathrm{kg}$ (based upon the estimated body weight), a positive end expiratory pressure (PEEP) of $4 \mathrm{~cm}$ water, and an inspiration to total cycle ratio of 0.4 . An umbilical artery catheter was placed and advanced to the abdominal aorta just below the diaphragm for purposes of recording blood pressure and heart rate and for monitoring blood gases and blood $\mathrm{pH}$. The blood pressure was monitored continuously. The blood gases and $\mathrm{pH}$ were determined immediately and thereafter at least every $30 \mathrm{~min}$.

The body temperature of each lamb was monitored with a rectal thermometer. In pilot experiments, the body temperature rapidly dropped to quite low levels, so in subsequent studies we employed both a heating blanket (Gaymar) under each fetus as well as an overhead heat lamp. By adjusting these, we were able to maintain the rectal temperature in the range of $37-38^{\circ}$. No attempt was made to correct the lamb's metabolic acidosis when it occurred. The respirator rates and volumes were altered in both twins, however, depending on the responses of the lambs including the results of the blood gases.

After $2 \mathrm{hr}$ of ventilation, each lamb that was still alive was sacrificed by cisternal injection of $2 \%$ Xylocaine. Immediately after the death of the animal (whether natural or induced) and while the lamb was still attached to the respirator the endotracheal tube was clamped at peak inspiration. At autopsy, the trachea was ligated and the chest was opened from the abdomen. The lungs and heart were carefully removed en bloc. The heart was removed and the entire lung was weighed. Portions of the lungs were removed and used as follows: right upper lobe for histology, histochemistry, and biochemical analysis (for phospholipid composition of surfactant fraction and residual fraction); right lower lobe for surface tension measurements; infracardiac lobe for lung water content; and the left lung for pressure-volume measurements.

\section{PREPARATION OF NATURAL SURFACTANT}

Fresh 2- to 3-day-old lamb lungs were perfused free of blood with cold $0.9 \%$ saline. The trachea was cannulated and the lungs were washed repeatedly with cold saline as reported previously (22). The turbid fluid washings were centrifuged at $200 \times g$ at $20^{\circ}$ for $7 \mathrm{~min}$ to remove the cell debris. The supernatant was further centrifuged at $1000 \times g$ at $2^{\circ}$ for $1 \mathrm{hr}$. The suspensions were pooled and again centrifuged at $100 \times g$ at $2^{\circ}$ for $1 \mathrm{hr}$. The pellet obtained was suspended in an equal volume of saline and resedimented at $200 \times g$ at $2^{\circ}$ for $10 \mathrm{~min}$ to remove the cell debris. This procedure was repeated until no yellow cellular layer was visible at the bottom. The resultant white layer was referred to as "natural surfactant." With this procedure it was possible to obtain as much as $250 \mathrm{mg}$ surfactant lipid from a 2-day-old newborn lamb.

\section{CHEMICAL COMPOSITION OF NATURAL SURFACTANT}

In order to determine the purity and reproducibility of the material isolated, compositional studies were performed in five preparations from eight newborn lambs. For lipid analysis, an aliquot of surfactant was lyophilized and the lipids were extracted with chloroform-methanol $(2: 1, \mathrm{vol} / \mathrm{vol})$ and washed by the method of Folch et al. (21). The total lipids were determined gravimetrically using a Cohn M-10 electrobalance. The phosphorus was determined by the method of Bartlett (6).

Individual phospholipid classes were quantitated by phosphorus analysis after separation by two-dimensional thin layer chromatography on silica gel $\mathrm{H}$-coated plates. The plates were developed in the first dimension using $\mathrm{CHCl}_{3}$-methanol-ammonia $(65: 35: 5)$, and in the second dimension using $\mathrm{CHCl}_{3}$-acetone-methanolacetic acid- $\mathrm{H}_{2} \mathrm{O}(5: 2: 1: 1: 0.5)$. The lipids on the plates were visu- alized using $2^{\prime}, 7^{\prime}$-dichlorofluorescein spray under UV light. The saturated phosphatidyl choline was determined by the method of Shimojo et al. (31). The neutral lipid classes, after separation by thin layer chromatography in ether petroleum ether-acetic acid, were estimated gravimetrically using a Cahn M-10 electrobalance. Protein was determined by the method of Lowry et al. (27) using crystalized bovine serum albumin, fraction $\mathrm{V}$, as the standard.

\section{PRESSURE-VOLUME MEASUREMENTS ON ISOLATED LEFT LUNG}

A metal cannula connected to a polyethylene tube $10 \mathrm{~mm}$ in diameter was inserted into the left main stem bronchus via the trachea and ligated tightly just below the level of the carina. The lung was degassed in a vacuum jar and placed in a saline water bath at $37^{\circ}$. The polyethylene tube was connected to a constant infusion pump (Harvard) with a syringe of $200 \mathrm{ml}$ and to a water manometer by a $\mathrm{T}$ tube. The lung was inflated with air over 7-17 min to $30 \mathrm{~cm} \mathrm{H}_{2} \mathrm{O}$ pressure in increments of $2.4 \mathrm{ml} / \mathrm{min}$ to avoid the stress relaxation phenomenon, and then was deflated in a similar fashion. The volume reached at $30 \mathrm{~cm} \mathrm{H}_{2} \mathrm{O}$ pressure was assumed to be the total lung capacity.

Pressure-volume curves of volume of gas per gram of lung tissue were derived from the pressure-volume measurements and weight using a computer plotter Wang model 600 . Gas volumes were determined by subtracting the tissue volumes measured by displacement in the water manometer. The gas volume per $\mathrm{g}$ lung tissue on deflation was used for comparison of the pressure-volume characteristics of each lung.

\section{LUNG WATER CONTENT}

The lung tissue of the infracardiac lobe was removed and weighed by a Right-A-Weight balance. The lung tissue was placed in an oven at $120^{\circ}$ for $24 \mathrm{hr}$, after which it was again weighed. The water content was calculated as follows:

Lung water content (\%)

$$
=\frac{(\text { lung wet weight })-(\text { lung dry weight })}{(\text { lung wet weight })} \times 100
$$

\section{LUNG SURFACE TENSION}

Three grams of lung tissue were taken from the right lower lobe and were prepared and used for surface tension measurements as reported previously (22). The surface activity of the saline extract was measured on a modified Wilhelmy balance. The surface area was cycled until a stable curve was recorded, and the highest and lowest tensions noted on the last cycle were recorded as $\gamma$ maximum and $\gamma$ minimum. The stability index (12) was also calculated.

\section{HISTOLOGIC AND HISTOCHEMICAL TECHNIQUES}

After the lungs were weighed, surgical scissors were used to cut a slice of lung, $5 \mathrm{~mm}$ thick, in a plane at right angles to the right upper lobe bronchus. The tissue was dropped into Elftman's dichromate-sublimate fixative, and was processed according to Elftman's recommendations (14-16), as described by Emmel and Cowdry (17).

Serial paraffin sections were cut at $6 \mathrm{~m} \mu$ and were stained both with routine histologic stains and with Sudan black and nuclear fast red, for localization of phospholipids. Sections of the whole lobe were studied under the light microscope at all degrees of magnification.

\section{RESULTS}

\section{GENERAL COMMENTS}

The emphasis of this report is on the clinical and physiologic effects of surfactant. Only brief mention will be made of the biochemical, histologic and histochemical findings, since they will be described in greater detail in subsequent reports. 
The immaturity of all the lambs was obvious for a number of reasons: their low body weights; the sparseness of their hair; the fusion of their eyelids, and their soft nailbeds. At the time of delivery, all lambs were active and in good condition as evidenced by normal umbilical vein blood $\mathrm{pH}, \mathrm{pO}_{2}$, and $\mathrm{pCO}_{2}$. Without exception, the "shake test" for surface activity was negative on the amniotic fluid and tracheal fluid of all the lambs. Furthermore, the amount of phosphatidyl choline in the surfactant fraction isolated from the :racheal fluid was very low $(0.07 \mathrm{mg} / 100 \mathrm{ml})$. Thus, none of the lambs studied had more than a trace amount of surfactant in the tracheal and amniotic fluids at the time of delivery.

\section{AMOUNT OF NATURAL SURFACTANT INSTILLED}

The amounts of natural surfactant instilled into the lungs of each of the experimental lambs are shown in Table 1 . The total lipids administered per $\mathrm{kg}$ body wt varied from 113-229 $\mathrm{mg}$ (mean 173 ) and the total lipids per $g$ lung wet wt from $2.5-5.8 \mathrm{mg}$ (mean 4.0). The total protein content contained in the surfactant administered varied from $40-76.9 \mathrm{mg}$ (mean 56.5 ).

\section{CHEMICAL COMPOSITION OF NATURAL SURFACTANT}

The chemical composition of the natural surfactant used is shown in Table 2 . These determinations were made on an aliquot of the material from eight newborn lambs 2-3 days of age. The average amount of total lipid was $18.5 \mathrm{mg} / \mathrm{ml}: 79 \%$ phospholipid and $54 \%$ saturated phosphatidyl choline. The average protein content was $4.1 \mathrm{mg} / \mathrm{ml}$, giving a lipid protein ratio of approximately $4: 1$. Phosphatidyl choline comprised $84 \%$ of the total phospholipid, and saturated phosphatidyl choline (predominantly dipalmitoyl lecithin) accounted for $62 \%$ of the phospholipid.

\section{EFFECTS OF SURFACTANT ON CLINICAL PARAMETERS}

The administration of natural surfactant had a striking effect on the clinical course of the experimental lambs in contrast with the control twins that received saline or distilled water. As shown in Table 3, all of the lambs that received surfactant survived for the full $2 \mathrm{hr}$, whereas all of the control lambs died prematurely, usually before $60 \mathrm{~min}$ (average $=48 \mathrm{~min}$ ).

Experimental lambs showed some spontaneous movement and responded promptly to painful stimuli, whereas control animals had no spontaneous movements with or without stimuli. On auscultation of the chest experimental lambs had predominantly vesicular breath sounds whereas control animals had bronchial breath sounds.

Figures, 1, 2, and 3 show a plot of the arterial $\mathrm{pH}, \mathrm{pO}_{2}$, and $\mathrm{pCO}_{2}$ against time for both the experimental and control lambs. All control lambs died with severe acidosis ( $\mathrm{pH}$ below 7.0) and most had hypercarbia and hypoxemia. In contrast, the experimental lambs had acceptable arterial blood $\mathrm{pH}, \mathrm{pO}_{2}$, and $\mathrm{pCO}_{2}$, considering that they received no bicarbonate and were ventilated on room air.

An attempt was made to ventilate all the lambs in a similar fashion with similar volumes of air $(5 \mathrm{ml} / \mathrm{kg})$. In all pairs of twins, the peak ventilation pressure of the suffactant treated lamb was lower than the control (Table 3 and Figure 4); in many, it was approximately one-half the pressure used in the control lamb $(P<0.001)$. Using the formula:

Effective compliance

$$
=\frac{\text { peak lung volume }}{\text { peak inspiratory pressure - PEEP }}
$$

the calculated effective compliance was strikingly different between the experimental and control lambs. Furthermore, the compliance of the lambs that received surfactant seemed to improve with time as shown in Figure 5.

\section{AUTOPSY APPEARANCE OF LUNGS}

The lungs of control animals were liver-like in appearance without exception. (Plate 1) The lungs of all lambs that received surfactant were aerated and their pleural surfaces looked like those of normal, full term breathing lambs. Where aeration was patchy the units that were either inflated or that were not, always followed the pattern of "pneumons" $(26,33)$.

\section{LUNG WATER CONTENT}

The lungs of both the experimental and control lambs (Table 3) remained wet (87-90\%) and were in the range of values observed in fetal life (3). Thus, the administration of surfactant did not

Table 2. Chemical composition of natural surfactant

\begin{tabular}{|c|c|c|}
\hline Total lipid & $18.5 \pm 5.3 \mathrm{mg} / \mathrm{ml}$ & \\
\hline Protein & $4.1 \pm 1.2 \mathrm{mg} / \mathrm{ml}$ & \\
\hline Lipid/protein ratio & $4.0 \pm 1.7$ & \\
\hline Phospholipid & $18.8 \pm 3.6 \mu \mathrm{mol} / \mathrm{ml}$ & \\
\hline Phosphatidyl choline & $15.7 \pm 2.2 \mu \mathrm{mol} / \mathrm{ml}$ & $84.1 \pm 4.1 \%$ of $P$ \\
\hline $\begin{array}{l}\text { Saturated phosphatidyl } \\
\text { choline }\end{array}$ & $12.9 \pm 1.4 \mu \mathrm{mol} / \mathrm{ml}$ & $61.5 \pm 7.8 \%$ of $P$ \\
\hline $\begin{array}{l}\text { Phosphatidyl ethanol- } \\
\text { amine }\end{array}$ & $1.0 \pm 0.2 \mu \mathrm{mol} / \mathrm{ml}$ & $4.6 \pm 0.7 \%$ of $P$ \\
\hline Sphingomyelin & $0.4 \pm 0.05 \mu \mathrm{mol} / \mathrm{ml}$ & $1.8 \pm 0.3 \%$ of $P$ \\
\hline Phosphatidyl glycerol & $0.9 \pm 0.4 \mu \mathrm{mol} / \mathrm{ml}$ & $4.4 \pm 1.8 \%$ of $P$ \\
\hline Phosphatidyl inositol & $0.09 \pm 0.001 \mu \mathrm{mol} / \mathrm{ml}$ & $0.4 \pm 0.01 \%$ of $P$ \\
\hline Phosphatidyl serine & $0.05 \pm 0.04 \mu \mathrm{mol} / \mathrm{ml}$ & $0.3 \pm 0.2 \%$ of $P$ \\
\hline
\end{tabular}

Table 1. Amount of natural surfactant instilled ${ }^{1}$

\begin{tabular}{|c|c|c|c|c|c|c|c|c|}
\hline Exp. no. & $\begin{array}{l}\text { Body } \\
\text { wt, kg }\end{array}$ & $\begin{array}{l}\text { Lung } \\
\text { wt, g }\end{array}$ & $\begin{array}{c}\text { Total lipids, } \\
\mathrm{mg} \\
\end{array}$ & $\begin{array}{c}\text { Total PL, } \\
\text { mg }\end{array}$ & $\begin{array}{c}\text { Total Sat PC, } \\
\text { mg }\end{array}$ & $\begin{array}{l}\text { Total lipids/ } \\
\text { kg BW, mg }\end{array}$ & $\begin{array}{c}\text { Total lipids/ } \\
\text { g LW, mg }\end{array}$ & $\begin{array}{c}\text { Total protein, } \\
\text { mg }\end{array}$ \\
\hline 452 & 1.7 & 82 & 375 & 322 & 153 & 221 & 4.6 & 53.7 \\
\hline 453 & 2.0 & 92 & 282 & 266 & 118 & 141 & 3.1 & 70.1 \\
\hline 454 & 1.7 & 90 & 277 & 252 & 118 & 163 & 3.1 & 76.9 \\
\hline 458 & 1.8 & 73 & 272 & 245 & 115 & 151 & 3.7 & 54.6 \\
\hline 459 & 1.2 & 54 & 136 & 113 & 54 & 113 & 2.5 & 40.0 \\
\hline 460 & 1.7 & 58 & 306 & 254 & 122 & 180 & 5.3 & 75.0 \\
\hline 461 & 2.0 & 89 & 275 & 208 & 104 & 138 & 3.1 & 48.0 \\
\hline 462 & 1.2 & 61 & 275 & 208 & 104 & 229 & 4.5 & 48.0 \\
\hline 465 & 1.5 & 65 & 265 & 202 & 107 & 177 & 4.1 & 48.8 \\
\hline 466 & 1.2 & 46 & 265 & 191 & 113 & 221 & 5.8 & 50.4 \\
\hline Mean & 1.6 & 71 & 273 & 226 & 111 & 173 & 4.0 & 56.6 \\
\hline $\pm S E$ & 0.1 & 5.2 & 18.4 & 17.6 & 7.7 & 12.6 & 0.3 & 4.0 \\
\hline
\end{tabular}

' BW: body weight; LW: lung weight; PL: phospholipid; Sat PC: saturated phosphatidyl choline. 
Table 3. Effects of surfactant or diluent on clinical and autopsy parameters in premature twin lambs

\begin{tabular}{|c|c|c|c|c|c|c|c|c|}
\hline Exp no. & $\begin{array}{l}\text { Body wt, } \\
\text { kg }\end{array}$ & Treatment & $\begin{array}{l}\text { Vent. pres- } \\
\text { sure, cm } \\
\mathrm{H}_{2} \mathrm{O}\end{array}$ & $\begin{array}{c}\text { Survival } \\
\text { time, min }\end{array}$ & Lung $\mathrm{H}_{2} \mathrm{O}, \%$ & $\begin{array}{c}\text { Vol in } \mathrm{ml} / \mathrm{g} \text { at } 7 \\
\mathrm{~cm} \text { pressure }\end{array}$ & $\begin{array}{l}\text { Minimum surface } \\
\text { tension, dynes/cm }\end{array}$ & $\begin{array}{l}\text { Stability in- } \\
\text { dex }\end{array}$ \\
\hline \multicolumn{9}{|l|}{452} \\
\hline A & 2.1 & Saline & $33 / 8$ & 97 & 88 & 0.1 & 29 & 0.5 \\
\hline B & 1.7 & Surfactant & $30 / 7$ & 120 & 86 & & 13 & 1.1 \\
\hline \multicolumn{9}{|l|}{453} \\
\hline A & 2.0 & Surfactant & $25 / 7$ & 120 & 88 & 0.5 & 5 & 1.6 \\
\hline B & 2.3 & Saline & $40 / 5$ & 35 & 90 & 0.1 & 22 & 0.7 \\
\hline \multicolumn{9}{|l|}{454} \\
\hline A & 1.7 & Saline & $28 / 5$ & 34 & 87 & 0.1 & 31 & 0.4 \\
\hline B & 1.7 & Surfactant & $17 / 6$ & 120 & 89 & 1.1 & 4 & 1.7 \\
\hline \multicolumn{9}{|l|}{458} \\
\hline A & 1.8 & Surfactant & $20 / 4$ & 120 & 87 & 0.9 & 2 & 1.8 \\
\hline B & 1.8 & Saline & $28 / 4$ & 37 & 88 & 0.1 & 21 & 0.8 \\
\hline \multicolumn{9}{|l|}{459} \\
\hline A & 1.3 & Saline & $35 / 5$ & 49 & 87 & 0.1 & 34 & 0.4 \\
\hline B & 1.2 & Surfactant & $20 / 5$ & 120 & 88 & 1.3 & 11 & 1.2 \\
\hline \multicolumn{9}{|l|}{460} \\
\hline A & 1.7 & Surfactant ${ }^{1}$ & $23 / 5$ & 120 & 88 & 1.1 & 8 & 1.4 \\
\hline B & 1.4 & Saline & $28 / 4$ & 91 & 89 & 0.1 & 25 & 0.7 \\
\hline \multicolumn{9}{|l|}{461} \\
\hline A & 2.0 & Water & $36 / 4$ & 27 & 89 & 0.1 & 32 & 0.5 \\
\hline B & 2.0 & Surfactant' & $19 / 3$ & 120 & 89 & 1.2 & 2 & 1.8 \\
\hline \multicolumn{9}{|l|}{462} \\
\hline A & 1.2 & Surfactant ${ }^{1}$ & $20 / 7$ & 120 & 90 & 1.4 & 5 & 1.7 \\
\hline B & 1.4 & Water & $33 / 5$ & 25 & 89 & 0.1 & 35 & 0.4 \\
\hline C & 1.1 & Nil & & 0 & 89 & 0.1 & 36 & 0.4 \\
\hline \multicolumn{9}{|l|}{465} \\
\hline A & 1.5 & Water & $29 / 5$ & 23 & 89 & 0.1 & 34 & 0.4 \\
\hline B & 1.5 & Surfactant ${ }^{1}$ & $20 / 5$ & 120 & 88 & 1.3 & 6 & 1.6 \\
\hline $\mathrm{C}$ & 1.3 & Nil & & 0 & 89 & 0 & 35 & 0.4 \\
\hline \multicolumn{9}{|l|}{466} \\
\hline A & 1.2 & Surfactant ${ }^{1}$ & $19 / 5$ & 120 & 88 & 0.6 & 2 & 1.8 \\
\hline B & 1.3 & Water & $37 / 5$ & 42 & 87 & 0.1 & 35 & 0.5 \\
\hline
\end{tabular}

${ }^{1}$ Surfactant in water.

seem to promote removal of lung fluid, although the histologic appearances suggested that fluid was redistributed from alveolar spaces to connective tissue and lymphatics.

\section{PRESSURE-VOLUME CHARACTERISTICS OF LUNG}

It was possible to measure the pressure-volume characteristics on the lungs of all lambs except $452 \mathrm{~B}$ where an air leak occurred. As shown in Table 3, the volume of air (in milliliters per $g$ wet lung tissue at $7 \mathrm{~cm} \mathrm{H}_{2} \mathrm{O}$ pressure on the deflation limb) was 2-10 times greater in the lambs that received surfactant $(P<0.001)$. The mean deflation limb values for the two groups of lambs are shown in Figure 6. The shape of the deflation pressure-volume curve at pressure $=0$ in surfactant treated lambs suggests air trapping and/or reduced lung recoil.

\section{LUNG SURFACE TENSION}

Without exception, the lambs that received surfactant had a low minimum surface tension on the Wilhelmy balance and a high calculated stability index (Table 3, Fig. 7). In contrast, the lungs of control lambs had a high minimum surface tension and a low calculated stability index $(P<0.001)$. The values for the control lambs were similar to those obtained in infants who had died of hyaline membrane disease (5).

\section{HISTOLOGIC AND HISTOCHEMICAL FINDINGS}

The five serial sections from each right upper lobe were studied under the light microscope, and microphotographs were often taken at all levels of magnification using objective lenses of $\times 1$, $\times 10, \times 25, \times 40$, and $\times 100$. Observations were made, and results recorded both in words and on a 4-point scale without initial reference to whether or not the specimens were from a control or a surfactant-treated animal. The observed differences, however, were so uniformly striking that the diagnosis was quickly obvious, even though the section stained for phospholipid (which invariably showed large quantities of the instilled surfactant) was left to the last.

The histologic and histochemical findings will be reported in detail elsewhere. A few representative photomicrographs are shown in Plate 1. In contrast with the control lambs, those that received surfactant showed: good alveolar expansion, less obvious lung fluid, no hyaline membranes, and virtually no peripheral epithelial cell damage.

\section{DISCUSSION}

Our strikingly favorable results on the prevention of respiratory distress syndrome in premature lambs by the endotracheal instillation of natural surfactant prior to the first breath are consistent with the earlier observations of Enhörning and his collaborators (18-20).

In some respects, the studies of Enhörning and his colleagues were not comparable to ours. In their first report (20), the rabbit fetuses were dead at the time surfactant was instilled and the values given for the volume of air introduced into the lung were obtained on the inflation limb of the pressure-volume measurements rather than the standard way on the deflation limb. Furthermore, there was considerable overlap in the results they obtained in the controls as compared with those receiving surfactant. In their second report (18), the rabbit fetuses were delivered after the death of the mother and it took 3 min to cannulate each fetus. 

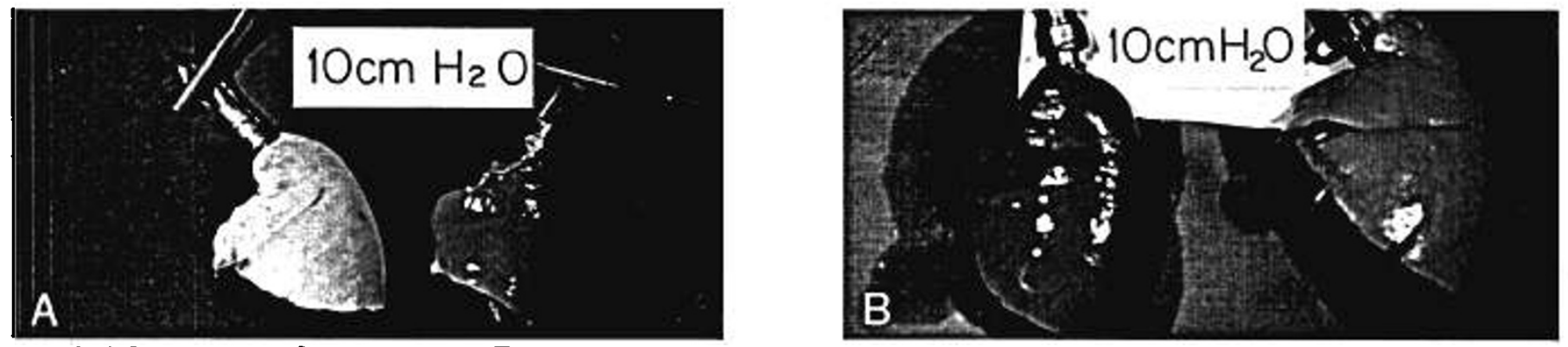
\#458 A
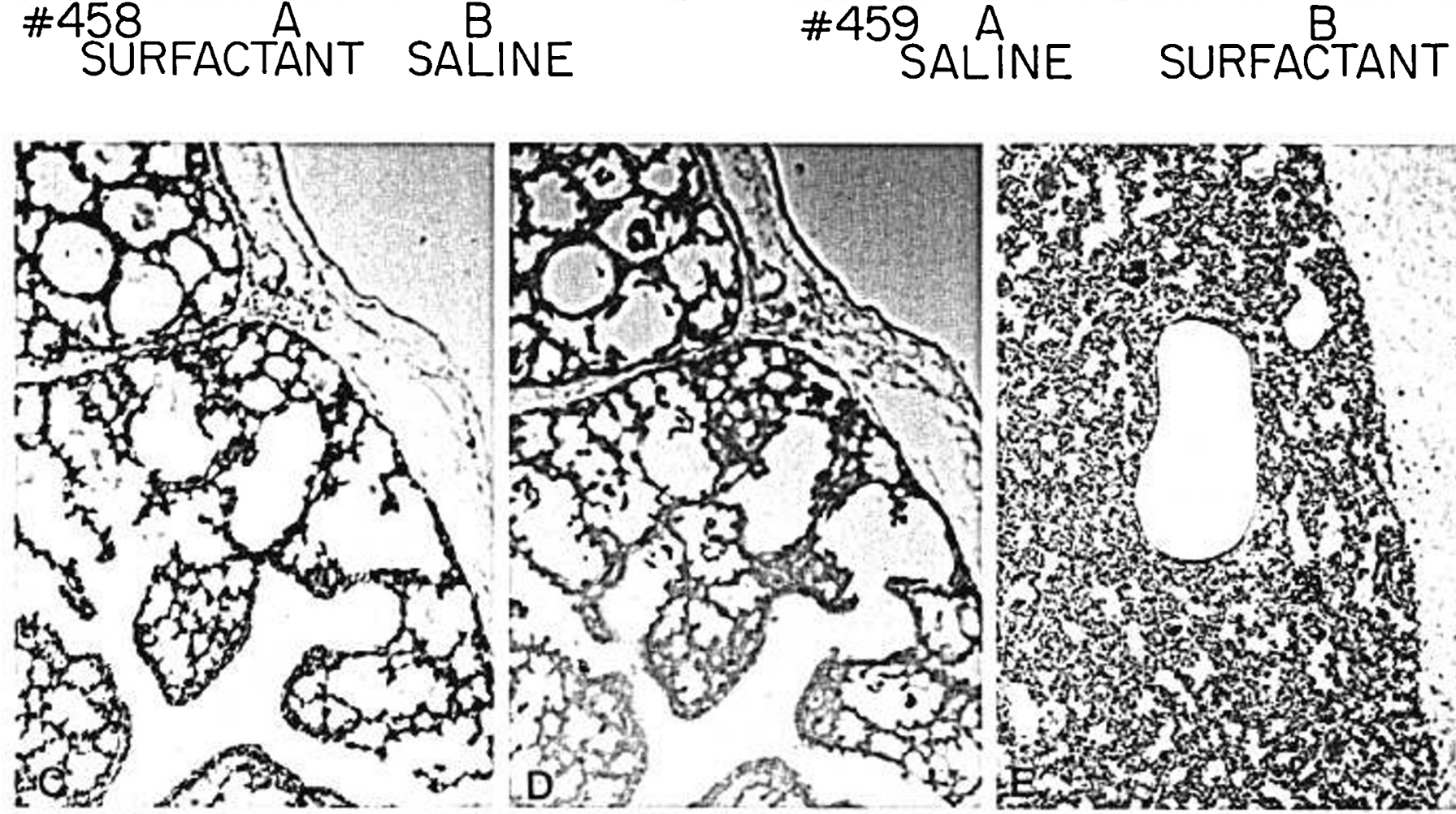

$n$ है
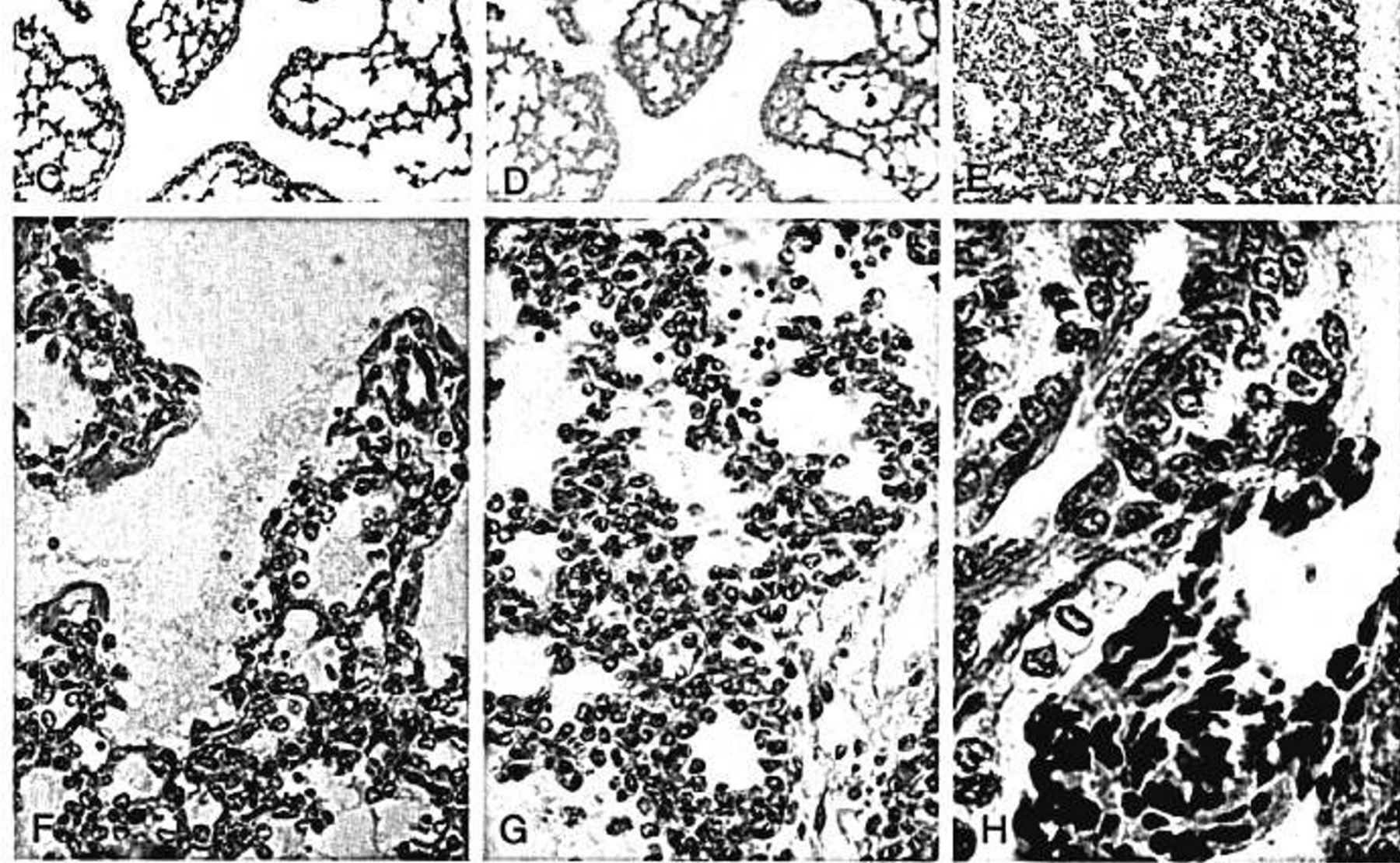

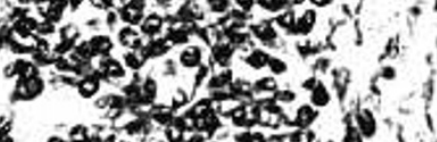
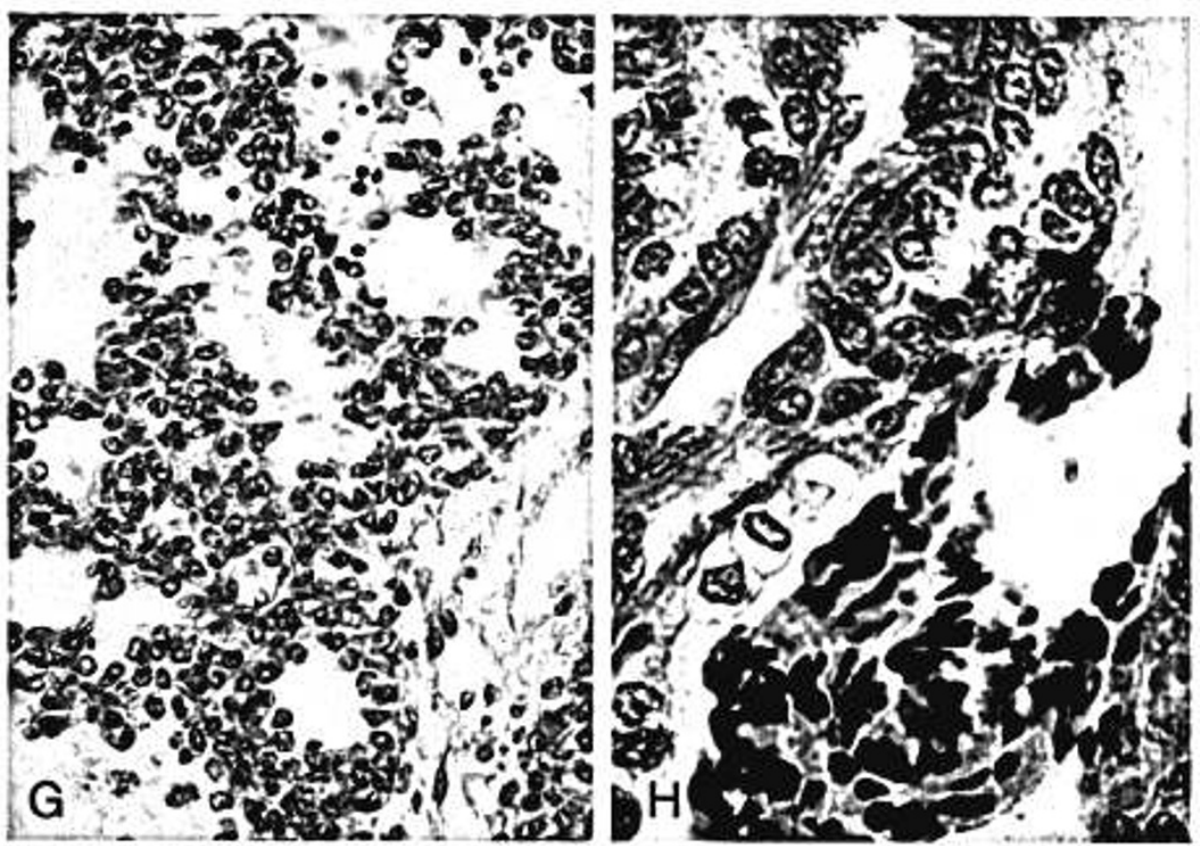

Plate 1. Photographs A and B from experiments 458 and 459 show the typical appearances of the left lungs inflated to $10 \mathrm{~cm} \mathrm{H}_{2} \mathrm{O}$ pressure. The lungs of the surfactant treated lambs are well inflated whereas the lungs of the control lambs appear "liver-like." Photomicrographs $C$ and D are adjacent sections of lung from surfactant-treated lamb 458A. In $\mathrm{C}$, note the even expansion of the terminal bronchiole and alveoli and normal epithelium (Masson's stain; $\times 35$ ). In D, note the deposition of phospholipid (black) in the lumina of two adjacent pneumons (Sudan black and nuclear fast red stain; $\times 35$ ). Photomicrographs E, F, G, and H are from control lambs (survival times in parentheses) 466B (42), 452A (97), 461A (27), and 458B (37), respectively. In E, note poor peripheral expansion and dilatation of small airways proximal to sites of epithelial cell plugging in respiratory and terminal bronchioles ( $\mathrm{H}$ and $\mathrm{E}$ stain; $\times 35$ ). In $\mathrm{F}$, note typical hyaline membranes at points of division of bronchioles and alveolar ducts (H and $\mathrm{E}$ stain: $\times 140$ ). In G, note epithelial cells with pycnotic nuclei lying both in alveolar walls and free in the lumina. At the top is a clump of dying cells in the lumen of a bronchiole ( $\mathrm{H}$ and $\mathrm{E}$ stain; $\times 140$ ). In $\mathrm{H}$, note the clump of dying cells in the lumen of a bronchiole whose epithelium looks healthy above and less so below (H and E stain; $\times 350$ ). Damaged epithelial cells are present peripherally after $27 \mathrm{~min}$ and typical hyaline membranes after $90 \mathrm{~min}$ of respirator therapy on room air. 
In our study, both the mother and the fetus were in good condition at the time of tracheal cannulation.

It would appear from rough calculation that we used considerably more surfactant in our studies than that reported by Enhörning et al. $(18,20)$. On an average we used $141.9 \mu \mathrm{g}$ total phospholipid/g body wt compared to their value of $5.1 \mu \mathrm{g} / \mathrm{g}$ body wt. Thus, our more favorable results may be in part due to the facts that our animals received larger amounts of surfactant and were artificially ventilated.

We were concerned over the possible adverse effects that the diluent might have on removal of alveolar and bronchial fluid since it is known that in dogs, endotracheally instilled saline disappears much more slowly from the lungs into the circulation than does plain water (29). In our small series, it did not seem to make a significant difference whether saline or distilled water was used as the diluent. Surfactant in saline or water seemed to produce less fluid microscopically in the alveoli and terminal bronchioles; however, both control and experimental lambs possessed very wet lungs (Table 3 ) similar to the fetal state (3). This

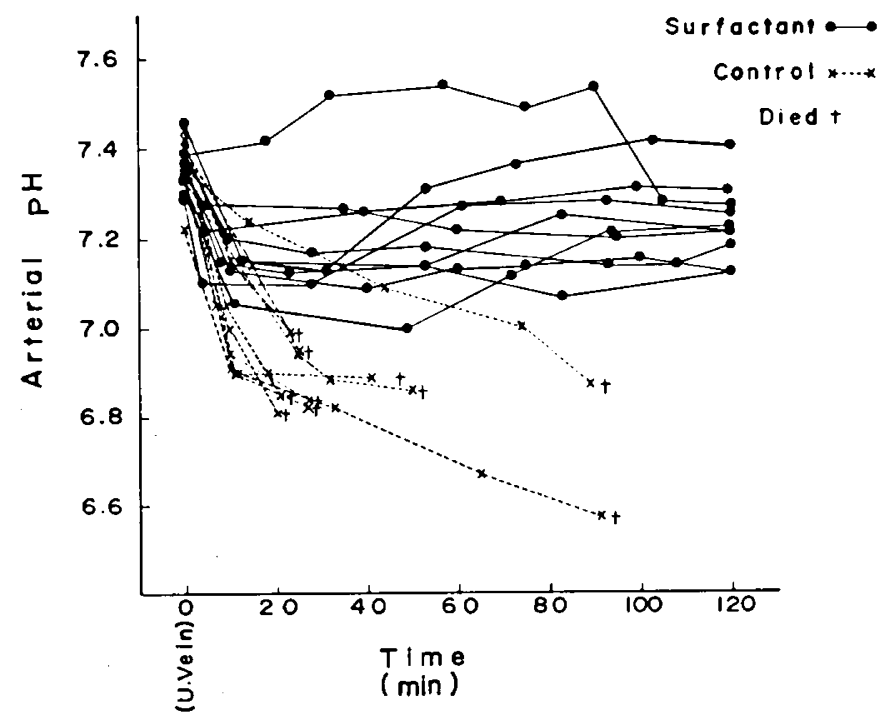

Fig. 1. Changes in arterial pH of surfactant-treated and contol lambs. Note, no bicarbonate was given to either group.

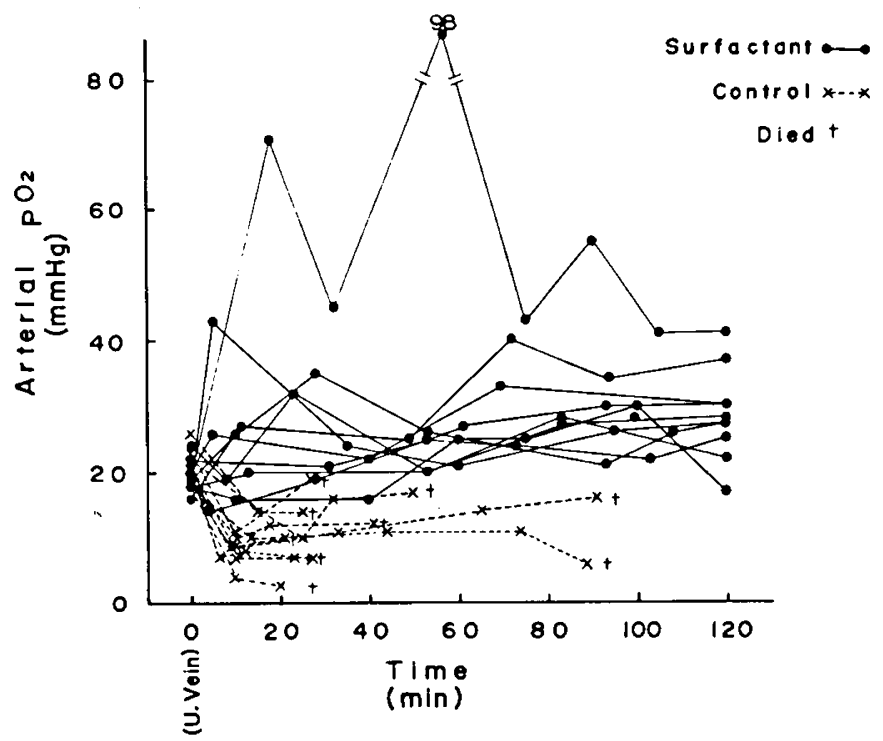

Fig. 2. Changes in arterial $\mathrm{pO}_{2}$ on room air of surfactant-treated and control lambs.

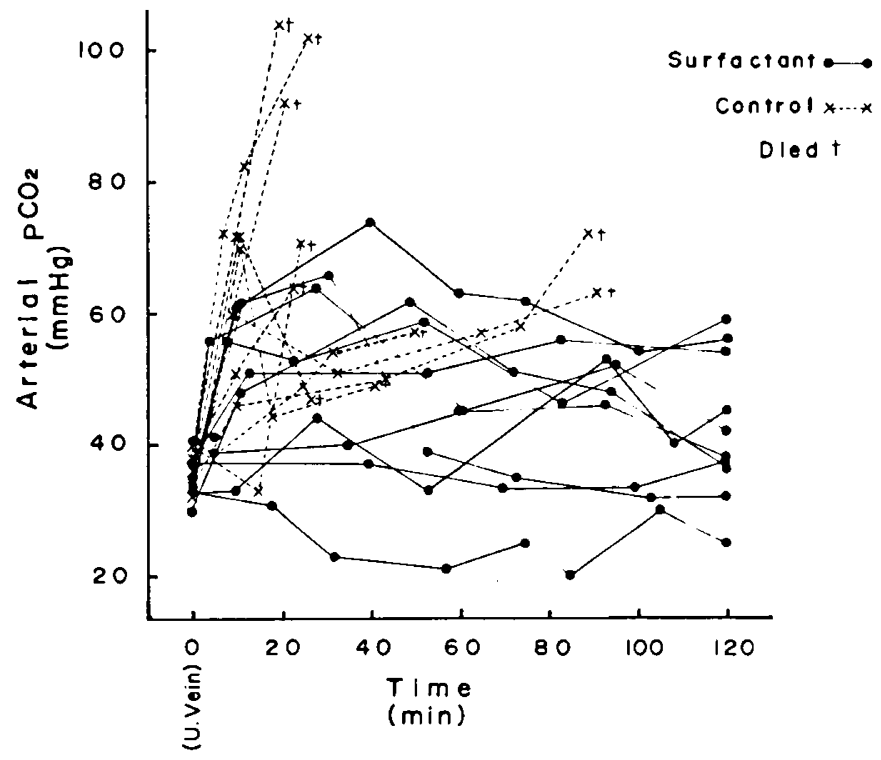

Fig. 3. Changes in arterial $\mathrm{pCO}_{2}$ of surfactant-treated and control lambs.

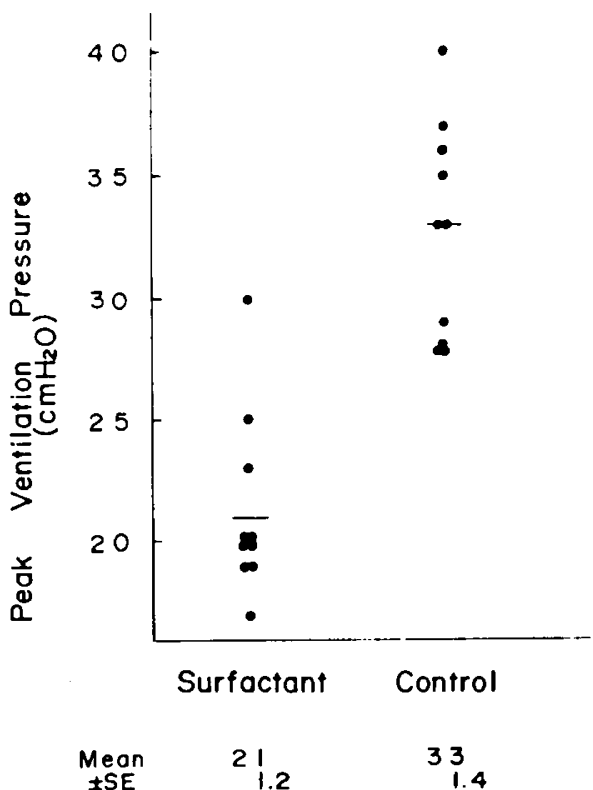

Fig. 4. Final peak ventilation pressure on respirator of surfactanttreated and control lambs (-: mean).

is not surprising since it is known that fetal lung fluid disappears slowly over a period of hours and days rather than minutes (4).

The prematurely delivered fetus has several additional features that puts it at a disadvantage in terms of the Starling equilibrium relative to fluid movement across a membrane: the colloid osmotic pressure of the plasma is known (28) to be low (12-16 torr in several of our experiments); the calculated pulmonary vascular resistance is higher than in adults (28); and most human premature infants have rather large left to right ductal shunts that can in turn produce pulmonary congestion and edema (32).

We are convinced that our immature lambs would not have survived without assisted ventilation. Very immature human infants also need such assisted ventilation frequently for long periods of time. Animal studies suggest the importance of PEEP and the need to keep the peak inspiratory pressure low (34). This was done in our studies. It may take some time, however, before the optimal mode of ventilation has been determined (7). 


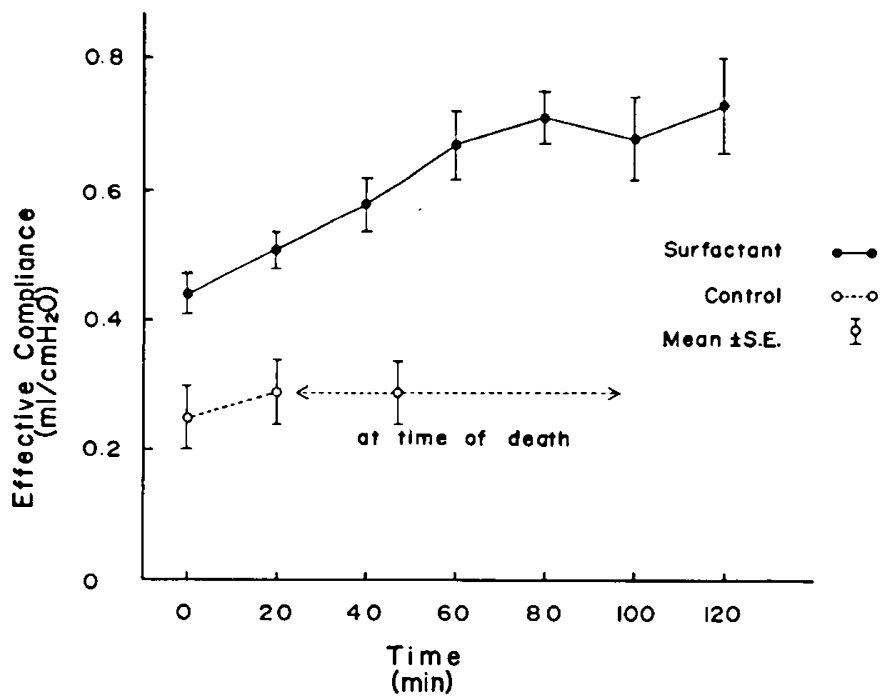

Fig. 5. Changes in effective lung compliance of surfactant-treated and control lambs.

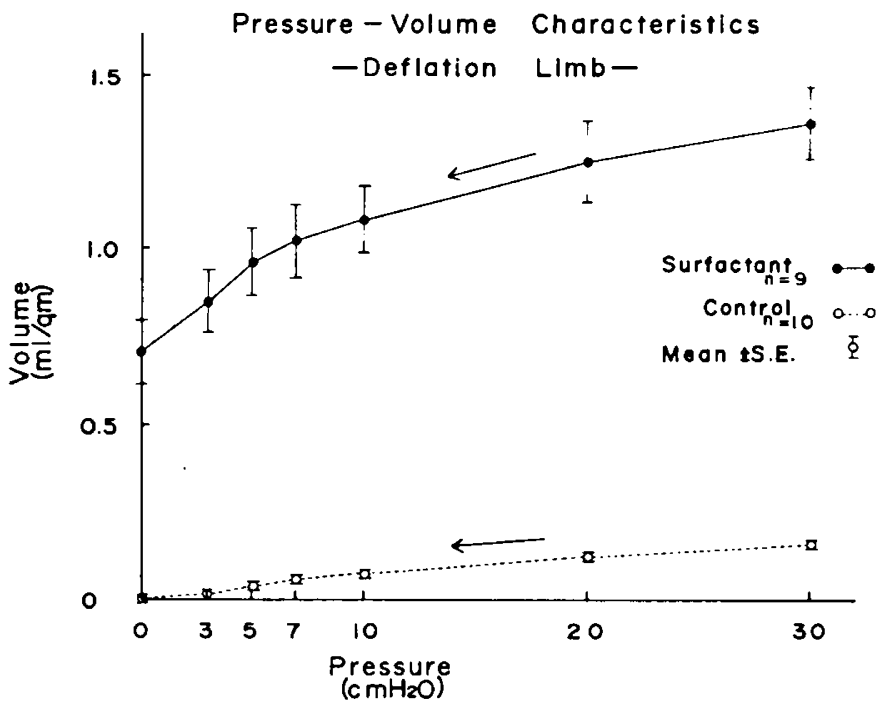

Fig. 6. Changes in pressure-volume characteristics on deflation limb of surfactant-treated and control lambs.

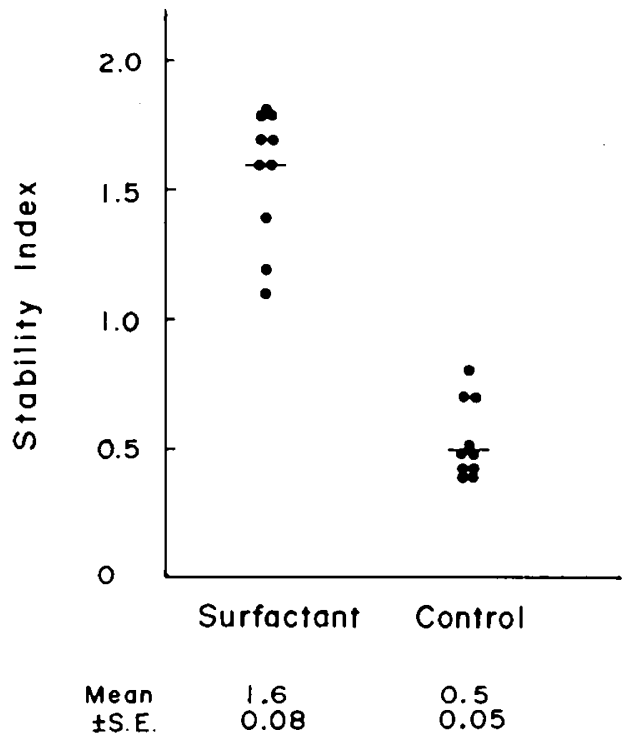

Fig. 7. Calculated stability index values from lung surface tension measurements of surfactant-treated and control lambs.
As stated earlier, the synthesis and secretion of surfactant by the cells of the fetal lung have been well studied in animals and humans $(1,3,8,22-24,33)$. It is also known that a large amount of surfactant is secreted into the alveolar space of the newborn after the onset of respiration $(1,3,23,24)$. Since the lung fluid of our fetal lambs contained only trace amounts of surfactant, and since the control lambs died so quickly, it can be assumed that our lambs were very immature and possessed very little releasable surfactant.

In our study each set of twin lambs was treated in a similar fashion except that one received natural surfactant and the other received diluent (saline or water). Except for the variation in the amount of surfactant that the experimental lambs received (Table 1), ours is a controlled study. Further investigations are still indicated however to answer such questions as: what is the optimal amount of surfactant that should be used; how long is a single dose of surfactant effective; how can surfactant best be administered after the onset of breathing; and is natural surfactant antigenic?

\section{REFERENCES AND NOTES}

1. Adarms, F. H., Fujiwara, T., Emmanouilides, G. C., and Räihä, N.: Lung phospholipids of human fetuses and infants with and without hyaline membrane disease. J. Pediat., 77: 833 (1970)

2. Adams, F. H., Fujiwara, T., Emanouilides, G. C., and Scudder, A.: Surface properties and lipids from lungs of infants with hyaline membrane disease. J. Pediat., 66: 357 (1965)

3. Adams, F. H., Fujiwara, T., and Latta, H.: "Alveolar" and whole lung phospholipids of premature newborn lambs. Biol. Neonat., 217: 198 (1971).

4. Adams, F. H., Yanagisawa, M., Kuzela, D., and Martinek, H.: The disappearance of fetal lung fluid following birth. J. Pediat., 78: 837 (1971).

5. Avery, M. E., and Mead, J.: Surface properties in relation to atelectasis and hyaline membrane disease. Amer. J. Dis. Child., 97: 517 (1959).

6. Bartlett, G. R.: Phosphorus assay in column chromatography. J. Biol. Chem., 234: 466 (1959).

7. Belenky, D. A.. Orr, R. J., Woodrum, D. E., and Hodson, W. A.: Is continuous transpulmonary pressure better than conventional respiratory management of hyaline membrane disease? A. controlled study. Pediatrics, 58: 800 (1976).

8. Brumley, G. W., Chernick, V., Hodson, A., Normand, C., Penner, A., and Avery, M. E.: Correlation of mechanical stability, morphology, pulmonary surfactant and phospholipid content in the developing lamb lung. J. Clin. Invest., 46: 863 (1967).

9. Brumley, G. W., Hodson, W. A., and Avery, M. E.: Lung phospholipids and surface tension correlations. Pediatrics, 40: 13 (1967).

10. Chu, J., Clements, J., Cotton, E., Klaus, M., Sweet, A., Thomas, M., and Tooley, W.: The hypoperfusion syndrome. Pediatrics, 35: 733 (1965)

11. Chu, J., Clements, J. A., Cotton, E. K., Klaus, M. H., Sweet, A. Y., and Tooley, W. H.: Neonatal pulmonary ischemia. Pediatrics, 40: 709 (1967).

12. Clements, J. A., Hustead, R. F.. Johnson, R. P., and Gribetz, I.: Pulmonary surface tension and alveolar stability. J. Appl. Physiol., 16: 444 (1961).

13. Clements, J. A., Platzker, A. C., et al.: Assessment of the risk of the respiratory distress syndrome by a rapid test for surfactant in amniotic fluid. New Engl J. Med., 286: 1077 (1972).

14. Elftman, H.: Controlled chromation. J. Histochem. Cytochem., 2: 18 (1954).

15. Elftman, H.: Phospholipid fixation by dichromate-sublimate. Stain Technol., 32: 29 (1957).

16. Elftman, H.: Effects of fixation in lipid histochemistry. J. Histochem. Cytochem., 6: 317 (1958).

17. Emmel, V., and Cowdry, E.: Laboratory Technique in Biology and Medicine, Ed. 4, p. 108, (Williams \& Wilkins, Baltimore, 1964).

18. Enhörning, G., Grossman, G., and Robertson, B.: Tracheal deposition of surfactant before the first breath. Amer. Rev. Resp. Dis., 107: 921 (1973).

19. Enhörning, G., Grossman, G., and Robertson, B.: Pharyngeal deposition of surfactant in the premature rabbit fetus. Biol. Neonate, 22: 126 (1973).

20. Enhörning, G., and Robertson, B.: Lung expansion in the premature rabbit fetus after tracheal deposition of surfactant. Pediatrics, 50: 58 (1972).

21. Folch, J., Lees, M., and Sloane-Stanley, G. H.: A simple method for the isolation and purification of total lipids from animal tissue. J. Biol. Chem., 226: 497 (1959).

22. Fujiwara, T., Adams, F. H., Sipos, S., and Salawy, A. E.: “Alveolar" and whole lung phospholipids of the developing fetal lamb. Amer. J. Physiol., 215: 375 (1968).

23. Fujiwara, T., Adams, F. H., Sipos, S., and Salawy, A. E.: "Alveolar" and whole lung phospholipids of newborn lambs. Proc. Soc. Exp. Biol. Med., 127: 962 (1968).

24. Gluck, L., Montoyama, E. K., Smits, H. L., and Kulovick, M. V.: The biochemical development of surface activity in mammalian lung. Pediat. Res, 1: 237 (1967)

25. Ikegami, M., Hesterberg, T., Nozaki, M., and Adams, F. H.: Restoration of lungpressure-volume characteristics with surfactant: Comparison of nebulization versus instillation and natural versus synthetic surfactant. Pediat. Res., 11: 178 (1977).

26. Lauweryns, J. M., and Rosan, R. C.: The unit lobule: A revised concept of the 
neonatal lung. Proceedings of the Second European Congress of Perinatal Medicine, London, 1970, p. 259 (Karger, Basel, 1971).

27. Lowry, O. H., Rosebrough, N. J., Farr, A. L., and Randall, R. J.: Protein measurement with the Folin phenol reagent. J. Biol. Chem., 193: 265 (1951).

28. Meschia, G.: Colloidal osmotic pressures of fetal and maternal plasmas of sheep and goats. Amer. J. Physiol., J81: 1 (1955).

29. Pearce M. L.: Sodium recovery from normal and edematous lungs studied by indicator dilution curves. Circ. Res., 24: 815 (1969).

30. Shannon, D. C., Kazemi, H., Merrill, E. W., Smith, K. A., and Wong, P. S.: Restoration of volume-pressure curves with a lecithin fog. J. Appl. Physiol.. 28: 470 (1970).

31. Shimojo, T., Abe, M., and Ohta, M.: A method for determination of saturated phosphatidyl choline. J. Lipid Res., 15: 525 (1974).

32. Thibeault, D. W., Emmanouilides, G. C., Nelson, R. J., Lachman, R. S., Rosengart. R. M. and Oh, W.: Patent ductus arteriosus complicating the respiratory distress syndrome in preterm infants. J. Pediat., 86: 120 (1975).
33. Towers, B.: The fetal and neonatal lung. In: N. S. Assali: The Biology of Gestation, Vol. II: The Fetus and Neonate, p. 189 (Academic Press, New York, 1968)

34. Webb, H., and Tierney, D. F.: Experiemntal pulmonary edema due to intermittent positive pressure ventilation with high inflation pressures: Protection by positive end-expiratory pressure. Amer. Rev. Resp. Dis., 110: 556 (1974).

35. The authors are indebted for help and advice and wish to thank the following: Donald F. Tierney, Bertrand Shapiro, Goran Enhörning. Bengt Robertson, Alex Sevanian, Takafumi Nagatomo, Tom Hesterberg, and John Zeller.

36. This research was supported by funds from the USPHS and the National Cystic Fibrosis Research Foundation.

37. Requests for reprints should be addressed to: Dr. Forrest H. Adams. Department of Pediatrics, Division of Cardiology, University of California School of Medicine. The Center for the Health Sciences, Los Angeles, CA 90024 (USA). 38. Received for publication September 9, 1977.

39. Accepted for publication October 26, 1977. 